\title{
Efektivitas Pemanfaatan Aplikasi Zoom Cloud Meeting Dalam Sosialisasi Program Kerja DKM Masjid Jami Darul Hikmah
}

\author{
Mari Rahmawati ${ }^{1}$, Wangsit Supeno ${ }^{2}$, Ade Fitria Lestari ${ }^{3}$, Etika Sabariah ${ }^{4}$ \\ Rusma Insan Nurachim ${ }^{5}$, Arief Setya Budi ${ }^{6}$ \\ 1,2,3,4,5 Universitas Bina Sarana Informatika \\ Jl. Kramat Raya No 98, Senen, Jakarta Pusat, Indonesia \\ ${ }^{6}$ STMIK Nusa Mandiri \\ Jl. Jatiwaringin Raya No 02 Jakarta Timur, Indonesia \\ e-mail: ${ }^{1}$ mari.mrw@bsi.ac.id, ${ }^{2}$ wangsit.wss@bsi.ac.id, ${ }^{3}$ ade.afr@bsi.ac.id, \\ ${ }^{4}$ etika.esb@bsi.ac.id, ${ }^{5}$ rusma.rsc@bsi.ac.id, ${ }^{6}$ arief.aeg@nusamandiri.ac.id
}

\begin{abstract}
Abstrak
Dewan Kemakmuran Mesjid (DKM) Masjid Jami Darul Hikmah memiliki susunan kepengurusan yang diantaranya bertanggung jawab dalam kegiatan program kerja rutin seperti pelaksanaan acara hari besar umat muslim, kerja bakti kebersihan masjid, pengembangan kegiatan masjid, pengembangan fasilitas dan sarana masjid. Oleh karena itu agar program kerja tetap berjalan tanpa kendala, maka salah satu teknologi tatap muka secara daring adalah salah satu solusi terbaik yang menjadikan primer problem solving. Hal ini dirasakan oleh pengurus dalam melakukan sosialiasasi kegiatan program kerja di saat kondisi pandemi Covid -19 saat ini. Pengurus kesulitan menyampaikan program kerja yang telah dirancang untuk dipresentasikan kepada Yayasan DKM Jami Darul Hikmah. Solusi dari permasalahan yang dihadapi pengurus adalah memanfaatkan teknologi informasi Zoom Cloud Meeting sebagai media meeting dan presentasi secara virtual dalam mensosialisasikan program kerja. Zoom Cloud Meeting selain sebagai media pembelajaran jarak jauh (PJJ) dapat juga dimanfaatkan sebagai sarana diskusi rapat secara online untuk mempresentasikan hasil kegiatan atau program kerja tersebut.
\end{abstract}

Kata Kunci: Dewan Kemakmuran Mesjid (DKM), Program Kerja, Aplikasi Zoom

\begin{abstract}
The Mosque Prosperity Council (DKM) of the Jami Darul Hikmah Mosque has a management structure which includes being responsible for routine work program activities such as implementing Muslim holidays, mosque cleaning services, developing mosque activities, developing mosque facilities and facilities. Therefore, in order to keep work programs running without problems, one of the face-to-face online technologies is one of the best solutions that makes primary problem solving. This was felt by the management in disseminating work program activities during the current Covid -19 pandemic conditions. The management had difficulty delivering the work program that had been designed to be presented to the Jami Darul Hikmah DKM Foundation. The solution to the problems faced by the board is to utilize Zoom Cloud Meeting information technology as a virtual meeting and presentation media in socializing work programs. Zoom Cloud Meeting apart from being a distance learning media (PJJ) can also be used as a means of online meeting discussions to present the results of these activities or work programs.
\end{abstract}

Keywords: Mosque Prosperity Council (DKM), Work Program, Zoom Application 


\section{Pendahuluan}

Era Dinamis dimana Teknologi dan peristiwa banyak terjadi secara tak terduga. Antara Peran Teknologi dan Perubahan Fenomena peristiwa yang terjadi, seakan tidak bisa diabaikan satu sama lainnya. Berbagai peristiwa seperti bencana alam dan pandemi merupakan peristiwa yang mengharuskan manusia tetap menjalankan aktivitas ekonomi (usaha dan kerja) dan aktivitas interaksi sosial, salah satunya menggunakan teknologi sebagai alat bantu atau perpanjangan tangan yang membantu kita mengatur dan mengendalikan segala urusan. Sejak bulan Januari 2020 terdengar isue tentang keberadaan Virus Covid-19 hingga mulai bulan Maret 2020 Negara Indonesia pun terdampak oleh bencana pandemi tersebut. Akan tetapi manusia tetap harus melakukan aktivitas dan bersosialisasi. Untuk mengatasi masalah tersebut aplikasi tatap muka melalui digital online adalah salah satu jawaban dalam menjawab masalah dalam menyelesaikan tugas dan bersosialisasi seperti yang dilakukan dalam kegiatan keagamaan dan kegiatan silaturahmi dan kegiatan kerja serta usaha.

Sosialisasi Kegiatan Program Kerja adalah jadwal rutinitas yang tidak bisa dihilangkan pada tahap pelaksanaan program kerja, karena tingkat keberhasilan program kerja tergantung pada keberhasilan sosialisasi visi, misi dan cara pelaksanaan yang dilakukan sehingga para anggota atau tim kerja berjalan pada role yang ditentukan. Kegiatan program kerja ada pada setiap institusi kerja, institusi usaha atau institusi sosial dan organisasi sosial pada ruang umum atau ruang keagamaan. Oleh karena itu Dewan Kemakmuran Mesjid (DKM) mempunyai ruang kerja yang disusun dengan koridor usaha melakukan 'amar ma'ruf nahi munkar untuk mengajak manusia ke jalan yang benar, melakukan aktifitas yang bernafaskan Islam di bidang da'wah, sosial, ekonomi dan pendidikan, dan memaksimalkan sumber daya manusia dalam rangka mengemban amanah umat untuk menjadikan masjid sebagai tempat beribadah yang nyaman. Sehingga terwujudnya masjid sebagai tempat peribadatan yang nyaman. Program kerja pada Ruang Keagamaan salah satunya adalah mengolah dana santunan, hibah, sumbangan, Zakat, Infaq dan Sodaqoh yang masuk pada program kerja pengembangan kegiatan masjid seperti santunan anak yatim piatu dan lain sebagainya.

Didalam pengembangan dana zakat, infaq dan sodaqoh telah diatur kedalam Undang-Undang Pengelolaan Zakat pada Undang-Undang Nomor 36 tahun 1999 tentang Pengelolaan Zakat disahkan dan diundangkan di Jakarta pada tanggal 23 September 1999 (Lembaran Negara Republik Indonesia Tahun 1999 Nomor 164, Tambahan Lembaran Negara Republik Indonesia Nomor 3885). Pada dasarnya, pemahaman pertama yang harus dimunculkan dengan adanya peraturan ini adalah, bahwa Negara menjamin warganya melaksanakan ajaran agamanya, melindungi fakir miskin dan untuk mewujudkan kesejahteraan masyarakat Indonesia sebagaimana tercantum dalam Pasal 5 ayat (1), Pasal 20 ayat (1), Pasal 29 dan Pasal 34 UUD 1945, maka pemerintah perlu membuat perangkat yuridis yang akan mendukung upaya tersebut. Kemudian lahirlah UU Nomor 38 tahun 1999 tentang Pengelolaan Zakat. Untuk melaksanakan UU tersebut muncul Keputusan Presiden Nomor 8 tahun 2001 tentang Badan Amil Zakat Nasional, yang di dalamnya mencantumkan perlunya tiga komponen untuk melaksanakan pengelolaan zakat, yaitu Badan Pelaksana, Dewan Pertimbangan dan Komisi Pengawas. (Azis, Muhammad, 2017).

Saat ini seluruh negara sedang dilanda wabah pandemi Covid-19 termasuk Indonesia, berdasarkan data dari https://covid19.go.id/ tercatat bahwa di bulan Januari 2021 ada sekitar 858.043 orang yang positif Covid-19. Kehadiran wabah Covid-19 mempengaruhi aktivitas kehidupan manusia seperti di bidang ekonomi melemahnya perekonomian dikarenakan jual beli 
yang semakin menurun, di bidang pendidikan para peserta didik mulai dari sekolah tingkat dini hingga perguruan tinggi menjalani pembelajaran jarak jauh (PJJ) secara virtual dan lain-lain. Hal tersebut dikarenakan adanya wabah ini mengakibatkan masyarakat dalam beraktivitas di luar rumah dibatasi agar tidak tertular. Zoom Cloud Meeting merupakan salah satu media video conference yang banyak digunakan, hal ini salah satunya dipicu oleh penyebaran virus covid19. Menurut Wibawanto dalam (Monica \& Fitriawati, 2020), aplikasi ini dinilai punya kualitas yang baik, dapat dibuktikan dengan perusahaan yang sudah masuk dalam fortune 500 yang sudah menggunakan layanan ini. Menurut Sidiq dalam (Ismawati \& Prasetyo, 2021) bahwa video conference dinilai juga efektif dalam mengatasi ruang jarak, dan waktu Zoom Cloud Meeting umumnya digunakan instansi pendidikan sebagai media pembelajaran jarak jauh (PJJ). Pemanfaatan video conference dalam pembelajaran jarak jauh dapat membantu anak didik dan pendidik dapat melakukan interaksi tatap muka meskipun tidak berdekatan (Monica \& Fitriawati, 2020)

\section{Metode}

\section{Solusi yang ditawarkan}

Pemecahan masalah dilakukan berdasarkan rumusan masalah yang telah diungkapkan dengan memberikan pemahaman kepada pengurus DKM masjid tentang efektifitas pemanfaatan aplikasi Zoom Cloud Meeting dalam sosialisasi kegiatan program kerja. Adapun langkah-langkah pemecahan masalah atau metode pelaksanaan sebagai berikut:

\section{a. Pemetaan (mapping)}

Memetakan permasalahan apa yang dihadapi dan solusi yang dibutuhkan. Hasil pemetaan diharapkan bisa memberikan gambaran keterampilan memecahkan masalah (Kurniawati \& Ramli, n.d.) yang dibutuhkan oleh pengurus DKM Masjid Darul Hikmah adalah penjelasan efektifitas pemanfaatan aplikasi Zoom Cloud Meeting dalam sosialisasi kegiatan program kerja.

\section{b. Wawancara}

Wawancara merupakan suatu teknik pengumpulan data secara langsung, saling bertukar pikiran dan informasi mengenai permasalahan yang di tentukan (Imtihan et al., n.d.). Wawancara dilakukan secara langsung kepada pengurus DKM Masjid Darul Hikmah untuk menetukan materi dan gambaran pemaparan tentang efektifitas pemanfaatan aplikasi Zoom Cloud Meeting.

c. Metode penyelesaian masalah

Pelatihan adalah adanya serangkaian aktivitas yang dirancang untuk meningkatkan keahlian-keahlian, pengetahuan, pengalaman ataupun perubahan sikap seseorang (Kewirausahaan \& 2018, n.d.). Dengan melakukan pelatihan kepada pengurus Masjid Darul Hikmah dapat menambah wawasan pentingnya penerapan aplikasi Zoom Cloud Meeting terhadap proses sosialisasi program kerja secara daring dengan tetap memperhatikan protokol kesehatan.

\section{d. Implementasi dan pelaksanaan}

Pelaksanaan acara dilakukan dengan menggunakan:

\section{1) Metode Ceramah}

Metode ceramah merupakan proses penyaluran informasi satu arah dari penyuluh kepada peserta atau sasaran penyuluhan, dimana metode ini cocok digunakan untuk sasaran dengan pendidikan tinggi maupun rendah dan mudah dalam perencaanaannya dan efisien waktu (Ningtyas et al., 2018). Memberikan 
pemahaman dan motivasi serta memberikan gambaran penerapan aplikasi Zoom Cloud Meeting pada kegiatan sosialisasi.

\section{2) Metode Tutorial}

Tutorial merupakan metode alternatif yaitu bacaan, demonstrasi, pengalaman yang membutuhkan respon serta ada ujian (Br Sembiring et al., 2018). Peserta dipandu secara langsung menggunakan aplikasi Zoom Cloud Meeting berdasarkan materi dan praktikum yang dilakukan.

3) Metode Diskusi

Diskusi merupakan suatu metode atau cara mengajar dengan cara memecahkan masalah yang dihadapi, baik atau lebih, dimana setiap peserta diskusi berhak mengajukan argumentasinya untuk memperkuat pendapatnya (Gustian et al., 2019). Melakukan diskusi tentang penerapan aplikasi Zoom Cloud Meeting kepada pengurus DKM Masjid Darul Hikmah pada sesi tanya jawab.

\section{Pelaksanaan Kegiatan}

Pengabdian masyarakat ini dilakukan melalui Zoom Meeting dengan pengurus DKM Masjid Darul Hikmah.

\section{Target Luaran}

a. Target pengabdian masyarakat

Terlaksananya kegiatan pengabdian masyarakat tentang efektifitas pemanfaatan aplikasi Zoom Cloud Meeting pada Masjid Darul Hikmah.

b. Luaran pengabdian masyarakat

Terlaksananya sosialisasi program kerja oleh pengurus DKM Masjid Darul Hikmah yang dihadiri para undangan dengan nyaman tanpa khawatir bertemu langsung mengingat pandemi Covid-19 dan tetap memperhatikan protokol kesehatan.

\section{Hasil dan Pembahasan}

Kegiatan Pengabdian Masyarakat yang dilaksanakan pada hari Sabtu, tanggal

September 2020 dengan menggunakan fasilitas Zoom Cloud Meeting, diikuti sebanyak 20 orang peserta yang merupakan Pengurus DKM Masjid Darul Hikmah Depok. Materi kegiatan Pengabdian Masyarakat adalah Pelatihan Efektivitas Pemanfaatan Aplikasi Zoom Cloud Meeting Dalam Sosialisasi Program Kerja DKM Masjid Darul Hikmah. Pelaksanaan pelatihan dilakukan secara online, dengan membahas teknis melakukan Sosialisasi Program Kerja DKM Masjid Darul Hikmah agar kegiatan rutin masjid dapat berjalan dengan baik dan efektif.

\section{Tahapan pelaksanaan pelatihan dilakukan sebagai berikut:}

1. Peserta pelatihan mempersiapkan Laptop yang terinstal Aplikasi Zoom Cloud Meeting.

2. Peserta pelatihan mengakses Link User dan Password Zoom Cloud Meeting.

3. Peserta mengikuti acara pelatihan dengan mengikuti penjelasan materi Efektivitas Pemanfaatan Aplikasi Zoom Cloud Meeting Dalam Sosialisasi Program Kerja DKM Masjid Darul Hikmah khususnya disaat pandemi untuk mencegah penularan virus Covid-19.

4. Peserta berlatih mempraktikan dan mengerjakan sebuah contoh Sosialisasi Program Kerja DKM Masjid Darul Hikmah dengan pemanfaatan Aplikasi Zoom Cloud Meeting. Di mana langkah pertama adalah melakukan instal Aplikasi Zoom Cloud Meeting kemudian Sign in dan membuat jadwal meeting untuk Sosialisasi Program Kerja DKM Masjid Darul Hikmah serta mempersiapkan link invitation yang akan dibagikan kepada peserta yang diundang.

5. Peserta berlatih mempraktikan membuat Meeting ID, Passcode dan melakukan setting peserta yang hanya menerima undangan saja yang bisa di admit untuk membuat acara aman dan nyaman. 


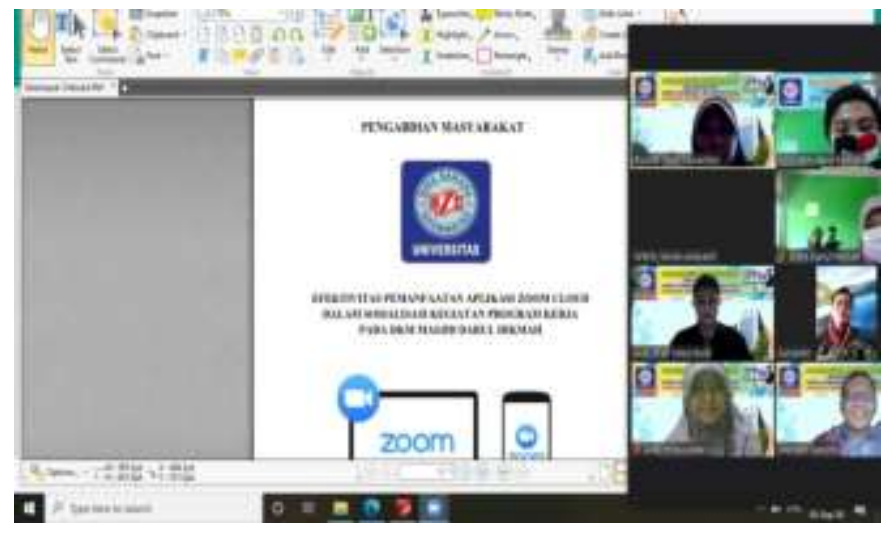

Gambar 1. Kegiatan Pelatihan

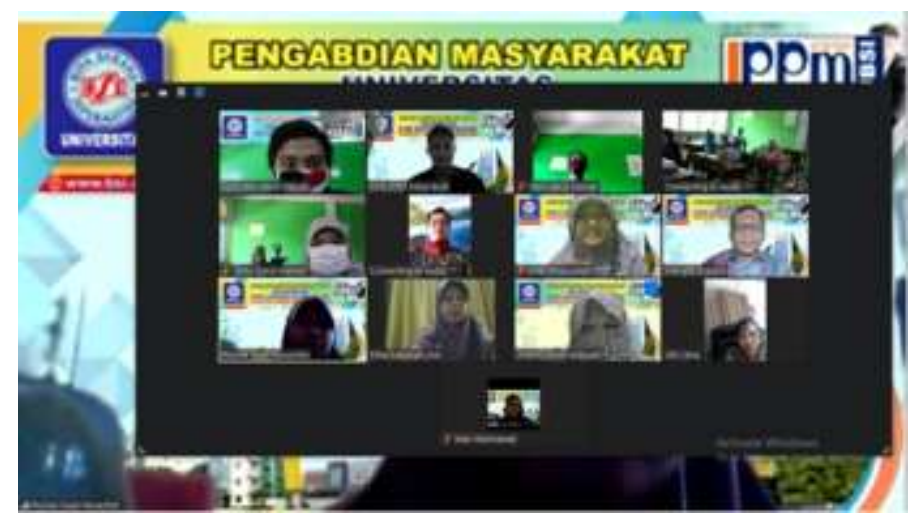

Gambar 2. Pemberian Materi Pelatihan

6. Peserta berlatih mempraktikkan penggunaan virtual background, cara setting dan penerapannya. Hal ini untuk mendukung fokus peserta bahwa acara yang dihadiri adalah sesuai dengan apa yang ada di dalam virtual background pembicara di Zoom Cloud Meeting.

7. Peserta berlatih mempraktikkan cara masuk ke dalam Zoom Cloud Meeting dan memulai acara meeting, mengganti virtual background dan menggunakan fungsi lain dari zoom yang umum dipakai seperti camera, audio dan video.

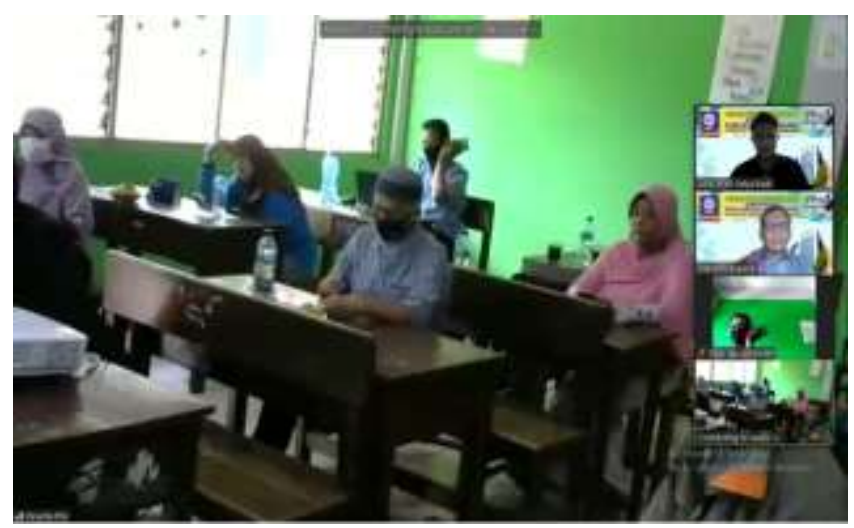

Gambar 3. Peserta Praktik Zoom Cloud Meeting

8. Peserta berlatih mempraktikkan cara memahami icon-icon yang ada agar penggunaan Zoom lebih efektif khususnya dalam acara penyampaian sosialisasi program kerja Masjid Darul 
Hikmah. Icon-icon tersebut adalah Icon Mic dan Video yang dipastikan dalam kondisi $O n$ untuk pembicara dan $O f f$ untuk peserta agar mencegah suara lain masuk dan mengganggu, kecuali dalam sesi tanya jawab atau diskusi. Icon jumlah partisipant yang menunjukkan jumlah peserta meeting yang hadir, untuk memonitor kehadiran orang-orang yang diundang. Selanjutnya icon record, yaitu memastikan acara direkam untuk dokumen dan yang terpenting adalah bagaimana peserta bisa praktik melakuka share materi sosialisasi DKM sehingga seluruh peserta bisa mengikutinya dengan jelas. Setelah pemaparan selesai biasanya akan ada tanya jawab, maka fungsi chat room akan sangat penting digunakan, sekalipun peserta bisa bertanya langsung, akan tetapi umumnya peserta lebih nyama menulis di menu chat room dan pada bagian akhir adalah bagaimana cara mengakhiri acara zoom dengan klik tombol Leave.

\section{Kesimpulan}

Berdasarkan pemaparan tersebut di atas, maka dapat diambil kesimpulan bahwa, pemanfaatan Aplikasi Zoom Cloud Meeting sangat tepat digunakan untuk keperluan sosialisasi program kerja pengurus DKM Masjid Darul Hikmah, terutama disaat kondisi pandemi, sehingga program kerja DKM bisa tetap dirancang dan disosialisasikan untuk diadakan, dengan menjaga protokol kesehatan, sehingga bisa mencegah resiko tertular Covid-19 karena tidak ada pertemuan secara fisik. Saran bagi para peserta pengurus DKM Masjid Darul Hikmah adalah untuk terus melakukan praktik sosialisasi program kerja, sebab dengan praktik bisa tahu cara yang efktif untuk menggunakan fasilitas Aplikasi Zoom Cloud Meeting. Dengan adanya Aplikasi Zoom Cloud Meeting Pengurus DKM Masjid Jami Darul Hikmah Depok dapat menjelaskan program kerja dan kegiatan dari pengurus DKM kepada masyarakat secara virtual. Sehingga agenda atau kegiatan sosial kemasyarakatan dapat tetap dilaksanakan meskipun dengan suasana yang sedikit berbeda. Protokol kesehatan pun tetap dapat diterapkan dengan efektif dengan pemanfaatan pertemuan virtual ini.

\section{Daftar Pustaka}

Aziz, Muhammad, 2017, Adopsi Hukum islam Dalam Sistem Hukum Nasional (kajian Dalam UU RI No. 23 Tahun 2011 Tentang Pengelolaan Zakat). Proceeding Ancoms 2017 1st Annual Conference for Muslim Scholars Kopertis Wilayah IV Surabaya.

Br Sembiring, E., Wahyuni, D., Wenang Anurogo, dan, Multimedia dan Jaringan, T., Negeri Batam, P., Geomatika, T., \& Ahmad Yani, J. (2018). Multimedia Interaktif Pengenalan Hewan Dan Tumbuhan Langka Menggunakan Model Tutorial. In Journal of Digital Education, Communication, and Arts Article History (Vol. 1, Issue 2). https://jurnal.polibatam.ac.id/index.php/DECA/article/view/839

Gustian, H., Jaenudin, J., Eosina, P., Teknik, J., Teknik, F., Ibn, U., Bogor, K., Kh, J., Km2, S. I., \& Bogor, K. (2019). Sistem Informasi Forum Diskusi Layanan Mandiri Online Warga Rw09 Kelurahan Karadenan Kecamatan Cibinong Kabupaten Bogor. In Ikra-Ith Informatika: Jurnal Komputer dan Informatika (Vol. 3, Issue 1). https://journals.upiyai.ac.id/index.php/ikraith-informatika/article/view/297

Imtihan, K., Informatika, M. B.-J. M., \& 2019, undefined. (n.d.). Sistem Informasi Pembuatan Manifest Muatan Kapal Berbasis Dekstop Dan Android. E-Journal.Stmiklombok.Ac.Id. Retrieved January 15, 2021, from http://e- journal.stmiklombok.ac.id/index.php/misi/ 
article/view/106

Ismawati, D., \& Prasetyo, I. (2021). Jurnal Obsesi : Jurnal Pendidikan Anak Usia Dini Efektivitas Pembelajaran Menggunakan Video Zoom Cloud Meeting pada Anak Usia Dini Era Pandemi Covid-19 Abstrak. 5(1), 665-675. https://doi.org/10.31004/obsesi.v5i1.671

Kewirausahaan, S. S.-O. J. E. dan, \& 2018, undefined. (n.d.). Pengaruh Pelatihan dan Motivasi terhadap Kinerja Karyawan. Jurnal.Unismabekasi.Ac.Id. Retrieved January 15, 2021, from http://jurnal.unismabekasi.ac.id/index.php/optimal/article/view/1544

Kurniawati, M., \& Ramli, M. (n.d.). Analisis Keterampilan Memecahkan Masalah Siswa SMA (Vol. 16, Issue 1).

Monica, J., \& Fitriawati, D. (2020). Efektivitas Penggunaan Aplikasi Zoom Sebagai Media Pembelajaran Online Pada Mahasiswa Saat Pandemi Covid-19 As An Online Learning Medium For Students During The Covid-19 Pandemic. 1, 1630-1640.

Ningtyas, I., Handayani, D., \& Kusumastuty, I. (2018). Pengetahuan Nutrition Facts dan Pemilihan Makanan Kemasan Mahasiswa Obesitas antara Metode Edukasi Personal dan Ceramah Nutrition Facts's Knowledge and Food Packaging Choice of Obese Students between Personal Education Method and Lecture Method. E-Journal.Unair.Ac.Id, 28-37. https://doi.org/10.2473/amnt.v2i3.2018 